\title{
Location decisions of sport manufacturing businesses in tourism destinations - analysing factors of attractiveness
}

\author{
Elisabeth Happ ${ }^{1, *}$ \\ 1 Department of Sport Science, University of Innsbruck, Innsbruck, Austria \\ * Corresponding author: MMMag. Elisabeth Happ, Department of Sport Science, University of Innsbruck, Fürstenweg 185, A-6020 Innsbruck, \\ Austria \\ Tel: +43 (0) 6504245825 \\ E-Mail: elisabeth.happ@uibk.ac.at
}

\section{ORIGINAL ARTICLE}

\section{Article History:}

Submitted $16^{\text {th }}$ May 2020

Accepted $21^{\text {st }}$ July 2020

Published $20^{\text {th }}$ August 2020

Handling Editor:

Otmar Weiß

University of Vienna, Austria

Editor-in-Chief:

Martin Kopp

University of Innsbruck, Austria

Reviewers:

Reviewer 1: anonymus

Reviewer 1: anonymus

\section{ABSTRACT}

Business location criteria and destination attractiveness have been widely studied a) in international business research and b) in tourism research. By contrast, studies about the attractiveness of tourism destinations as possible business locations for sport manufacturing companies have barely been examined. In order to contribute to closing this research gap, this quantitative study provides insights based on destination attractiveness by analysing sport, tourism, and specific economic attractiveness variables (conducted in the German-speaking Alps; $\mathrm{N}=119$ sport manufacturing companies; based on the Competitiveness Theory of Porter). These variables are represented by nine factors measured by 36 items considered pertinent for alpine tourism destinations. Furthermore, hierarchical regression analyses were used to explore factors influencing the attractiveness of a location for sport manufacturing companies, whilst the importance of different statements was evaluated. Results show that 1) the sport-specific factor "Sport Events" influences the attractiveness of sport manufacturing locations, 2) differences between Tyrol and other regions were identified relating to the importance of specific factors. Furthermore, implications were derived for governments and destination managers, allowing conclusions to be drawn about competitive advantages. Based on the results, destination benchmarking and benchmarking initiatives can be identified for the future.

Keywords:

alpine tourism destination - destination attractiveness - destination competitiveness - sport manufacturing business - location criteria

\section{Citation:}

Happ, E. (2020). Location decisions of sport manufacturing businesses in tourism destinations - analysing factors of attractiveness. Current Issues in Sport Science, 5:006. doi: 10.36950/2020ciss006.

\section{Introduction}

The pressure exerted by competition is compelling. International, national, state, and local governments and destinations have to re-evaluate their existing resources and reposition themselves to remain competitive. Some regions, destinations or sites appear to be more successful and attractive than others (Formica \& Uysal, 2006).

Many leading sport manufacturing companies that specialise in winter sports and outdoor equipment were founded in the Alps or have their headquarters (including management, sales, and marketing; excluding manufacturing) located in the Alps
(Spoteo, 2019). The Alps certainly do not attract sport manufacturing companies with cheap real estate and inexpensive labour costs, so there must be other reasons why the Alps are perceived as such an attractive location for sport manufacturing companies.

The Alps could be researched through the lens of tourism and tourism destination competitiveness (e.g. Crouch \& Ritchie, 1995, 1999; Dwyer \& Kim, 2003; Dwyer, Dragićević, Armenski, Mihalič, \& Knežević Cvelbar, 2016). However, this raises the question of whether an understanding of the factors influencing a tourist's location decision is at all relevant when making business location decisions. Authors like Porter (e.g. 1990) and 
Dunning (e.g. 1993; 2007) have dealt extensively with international business research on foreign-location choice. Additionally, Onstein, Tavasszy \& van Damme (2019) identified in their literature review three relevant streams of decisions relating to location choice: supply chain management, transport and geography.

There is something to be gained from the economic approach to location choice, but also from the tourist approach to location choice, as the Alps are neither a typical industrial location nor an exclusive tourism location. It might, therefore, be both relevant and interesting for the research community to consider the location choices of sport manufacturing companies in the Alps from both perspectives, from the tourism perspective as well as from the purely economic perspective of management.

Compared to many company locations all over the world, the Alps have, amongst other things, their natural environment as their main selling point as a nature-based destination (Huybers \& Bennett, 2003). Furthermore, the Alps are influenced by tourism, ranking among the most important global tourist destinations and attracting about 500 million visitors a year; moreover, tourism is a major source of income from both winter sports and summer tourism (Schirpke, Meisch, Marsoner, \& Tappeiner, 2018). As a result, sport manufacturing businesses could be swayed by these peculiarities in their choice of location. Furthermore, as opposed to other business types, sport is often described as an emotional and culturally unique business (Gammelsæter, 2020). In the mountains, visual appeal, terrain that lends itself to sport and a favourable climate represent the pull factors of these destinations (Pan \& Ryan, 2007). Research at the destination level shows that the economic environment is less important for the development of mountain destinations than other factors such as the natural, sociocultural, political, legal and technological environment (Kuščer \& Mihalič, 2014). Furthermore, Onstein, Tavasszy and van Damme (2019) identified geography as one research stream in the location decision literature of management and called for more research.

In other words, the Alps are a region where land that can be used by sport manufacturing companies is in limited supply. The infrastructure, such as transport connections to other regions, is associated with high financial costs and again, is limited, whilst land prices are relatively high compared to other regions. Nonetheless, many sport manufacturing companies are located in the Alps. These particularities make it compelling to examine this region in the context of the location decision factors of sports manufacturing companies. Indeed, there may also be a difference between the sport manufacturing businesses and other business sectors (Szymanski, 2009).

Tourism literature (Hu \& Ritchie, 1993; Reitsamer, BrunnerSperdin, \& Stokburger-Sauer, 2016, Wang et al., 2019, Yacob, Johannes, \& Qomariyah, 2019) and management literature (Balbontin \& Henser, 2019; Dixit, Clouse, \& Turken, 2019; Dziemianowicz, Lukomska, \& Ambroziak, 2019; Onstein, Tavasszy, \& van Damme, 2019) have paid much attention to location choice, but have largely neglected to define an overall framework for the variables influencing the appeal of alpine tourism destinations for sport manufacturing businesses looking for a new location, as seen through the lens of both tourism and management, whilst taking into consideration the peculiarities of sport. The main interest of researchers and experts is not related to the theoretical investigation of the attractiveness concept and subsequently to the competitive ability of a destination; the main concern is to examine the possibility of finding universal indicators and methods of measurement (Formica \& Uysal, 2006).

The abovementioned questions may seem easy to understand, as they deal with the qualitative and quantitative superiority of a unit; the concept, however, is much more complex. This becomes evident when we seek to define and measure the indicators influencing the attractiveness of destinations (Cracolici \& Nijkamp, 2008). The primary objective of this study is to gain a profound understanding of destination attractiveness by analysing sport, tourism, and specific economic attractiveness variables, and to determine how it influences the location choices of sport manufacturing businesses in the Alps by considering both the tourism and management perspectives.

A sport manufacturing business is defined in this context as a business to business entrepreneurship in the sport sector (including sporting goods manufacturers and the ropeway industry; excluding sport tourism suppliers and retailers). In this contribution, location is defined as the place where the company is situated. Furthermore, the surrounding region where the company is located is referred to as the destination in this context.

\section{Theoretical framework - competitiveness and factors of attractiveness in business location decisions}

Attractiveness refers to the extent to which the availability, quality, and management of services as well as infrastructure of a destination satisfy the needs of the stakeholders e.g. sport manufacturing business (in accordance with Cracolici \& Nijkamp, 2008). Uysal and Formica (2006) as well as Cracolici and Nijkamp (2008) studied destination attractiveness in detail and came to the conclusion that attractiveness is evaluated indirectly by a destination's competitive ability. A destination's capability and attractiveness reflect its ability to achieve its goals and provide its stakeholders with greater value (competitive advantage) than other destinations (Grant, 2005).

Therefore, competitiveness and competitiveness theories play a key role in attractiveness studies (Cracolici \& Nijkamp, 2008) and lead straight to the well-known competitiveness theory of Porter (1990) - Porter's Diamond Model. The complexity of Porter's concept becomes evident when we seek to define and measure it: due to the great variety of perspectives on competitiveness, giving a proper definition is difficult (Porter, 1990). Nevertheless, Porter has made a significant contribution to the literature by providing a comprehensive understanding of national and regional competitiveness in terms of tourism and 
management (Kim \& Wicks, 2010) and by describing the dimensions of attractiveness in terms of a destination or business organisation (Cracolici \& Nijcamp, 2008).

Competitiveness and factors of attractiveness in management literature

Competitiveness originates from the Latin word "competer", which means "involvement in business rivalry for markets". Academically, the roots of competitiveness studies lie in the international economic theories of Adam Smith and his followers (Bhawsar \& Chattopadhyay, 2015). Competitiveness frameworks - such as those of Dunning (1993) or D'Cruz \& Rugmann (1993), to name just a few - have become a paradigm for competitiveness analysis and have been researched empirically in many fields.

Some of the most recent reviews of competitiveness and of literature relating to foreign-location choices were penned by Ahsan and Musteen (2011), Deng (2012), Kim and Aguilera (2016) and Onstein et al. (2019). They demonstrate that international business research on literature relating to foreign-location choices has experienced a renaissance in recent years.

Moreover, specific topics have been repeatedly highlighted over the years in an attempt to take the changing times into account. Some of the latest research approaches in terms of business location choices in management literature include: a) research on firms focusing on specific activities and why they choose particular areas (e.g. Goerzen et al., 2013); b) location decisions adding place image to the economic factors (e.g. Dixit et al., 2019); c) the importance of local authorities in location decisions (e.g. Marks-Bielska \& Serocka, 2018), d) the debate of hard factors describing structural organisational characteristics in contrast to soft factors, which refer to non-structural organisational characteristics (e.g. Homburg \& Giering, 2003), e) literature review of location choice (Onstein et al., 2019) and f) scattered research on sport industry businesses in particular (e.g. Lohman, Fortuin, \& Wouters, 2004; Liu, 2016). Nevertheless, geographic space in combination with location decisions in international business has remained relatively underdeveloped in the literature (Alcacer, Dezsö, \& Zhao, 2013, Onstein et al., 2019).

Competitiveness and factors of attractiveness in tourism literature

The concept of destination attractiveness and its measurement have been studied extensively by tourism researchers, economists, and policy makers (Dwyer, Knežević Cvelbar, Mihalič, \& Koman, 2014; Formica \& Uysal, 2006; Lee, Huang, \& Huery-Ren, 2010). Several studies have examined the competitiveness of destinations using different models (e.g. Crouch, 2011; Enright \& Newton, 2004; Dwyer \& Kim, 2003; Zehrer, Smeral, \& Hallmann, 2016). Ritchie and Crouch (2003), for example, based their conceptual model on Porter's “Dia- mond of National Competitiveness". It consists of five dimensions (Crouch, 2011) and could be seen as the most comprehensive, rigorous and complex approach of all (Tsai, Song, \& Wong, 2009).

Consequently, the analysis and measurement of the attractiveness and subsequently of the competitiveness of a destination have been dominant themes in recent tourism literature (Andrades, Sanchez, \& Pulido, 2012; Crouch, 2011; Dwyer \& Kim, 2003; Pechlaner, Pichler, \& Herntrei, 2012). In addition to the development of comprehensive frameworks (Dwyer \& Kim, 2003; Ritchie \& Crouch, 2003; WEF, 2015), studies on single destinations (d'Hauteserre, 2000; Enright \& Newton, 2004; Dwyer, Knežević Cvelbar, Edwards, \& Mihalič, 2013; Dwyer, Knežević Cvelbar, Mihalič, \& Koman, 2014; Dwyer et al., 2014; Omerzel, Gomezelj, \& Mihalič, 2008), on comparisons of destinations (Enright \& Newton, 2005; Kozak, 2003), and studies focusing on specific attributes of competitiveness such as price competitiveness, environmental competitiveness, and business performance (Assaf \& Dwyer, 2013; Barros, Botti, Peypoch, Robinot, Solonandrasana, \& Assaf, 2011; Buhalis, 2000; Dwyer, Forsyth, \& Rao, 2000; Mihalič, 2000 ) have been conducted.

Kim and Aguilera (2016) followed the call for research on foreign location choices that goes beyond multiple disciplinary boundaries. In the context of the study in hand, one has to take into consideration that there are distinct and special features which make sport a unique business institution (Gammelsæter, 2020; Hess, Nicholson, \& Stewart, 2008; Mangan \& Nauright, 2000; Slack, 2003). Funk (2017) highlighted the lack of approaches from other disciplines, extending them to fit a sport context.

Considering all this scientific knowledge, the objective of this research is to increase our understanding of factors influencing the sport manufacturing business in terms of location choices in alpine tourism destinations by using the example of Tyrol and its neighbouring markets (eastern parts of Austria, parts of Germany, Switzerland and Italy). The key questions addressed in this study are: First, "What are the main factors that determine the attractiveness of a location for sport manufacturing companies?", and second, "Which criterias are most important for sport manufacturing businesses when making location decisions?". Based on the findings in the literature, the following hypotheses are proposed:

Hypothesis 1: Sport events positively affect the attractiveness of a location for sport manufacturing businesses.

Hypothesis 2: Sport infrastructure positively affects the at tractiveness of a location for sport manufacturing businesses.

Hypothesis 3: Tourism and marketing positively affect the attractiveness of a location for sport manufacturing businesses.

Hypothesis 4: Burden and bureaucracy positively?/negatively? affect the attractiveness of a location for sport manufacturing businesses. 
Hypothesis 5: Transport links positively affect the attractiveness of a location for sport manufacturing businesses.

Hypothesis 6: Political framework positively affects the attractiveness of a location for sport manufacturing businesses.

Hypothesis 7: Quality of life and medical care positively affect the attractiveness of a location for sport manufacturing businesses.

Hypothesis 8: Employment and education positively affect the attractiveness of a location for sport manufacturing businesses.

Hypothesis 9: Industry and innovation positively affect the attractiveness of a location for sport manufacturing businesses.

\section{Conceptual approach}

In an attempt to fill the identified research gaps, the competitiveness theory (Porter, 1990) was considered as the most suitable theory for identifying destination attractiveness indicators in the context of location choices for sport manufacturing businesses in a sport and tourism destination context. Porter's model made a comprehensive contribution to the understanding of national and regional competitiveness in tourism and management (Kim \& Wicks, 2010).

\section{Method}

First, the current study consists of an exploratory factor analysis and hierarchical regression analyses, exploring the factors influencing the attractiveness of a location for sport manufacturing companies (RQ \#1). Second, a descriptive analysis gives an overview of the items that scored highest in the overall sample, in terms of location choice for sport manufacturing businesses (RQ \#2).

The destination competitiveness and management literature highlights a substantial number of variables or drivers for destination competitiveness. Based on the existing literature (Crouch, 2011; Dwyer \& Kim, 2003; Enright \& Newton, 2004; Hudson, Ritchie, \& Timur, 2004; Knoll, 2004; Sieber, 2008; Zehrer et al., 2016), an online questionnaire was developed. The scale was defined to articulate the meaning and domain of attractiveness for sport manufacturing businesses looking to settle in alpine tourism destinations, and was based on insights from the literature. Finally, the questionnaire dealt with different topics: (1) Sport Events \& Culture, (2) Sport Tourism \& Hospitality, (3) Sport \& Environment, (4) Sport Apprenticeship \& Resident Population, (5) Sport \& Economy, (6) Sport Infrastructure $\&$ Facilities, and (7) Sport Policy \& Security. The items were derived from literature (see Appendix $A$ ) and modified to suit the context of sport.

In addition to the abovementioned variables examining destination attractiveness, company representatives were asked to

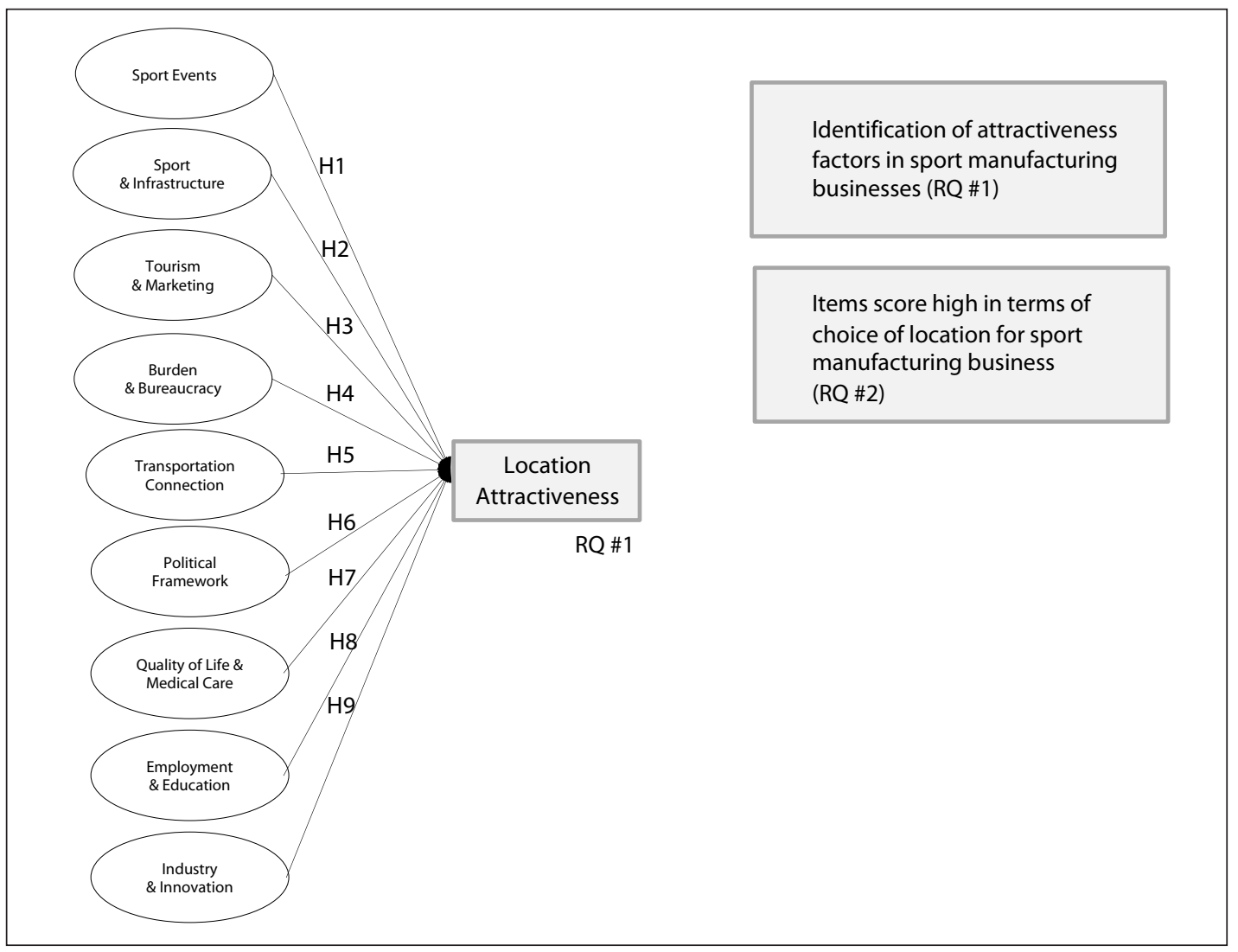

Figure 1. Conceptual approach of location attractiveness and influencing factors 
answer questions concerning overall attractiveness, attractiveness of certain destinations, importance of different variables affecting a location's attractiveness, recommendation rate for certain destinations, and how likely they would be to change their business location (see Appendix A for more details).

The online questionnaire was pretested and sent to 693 sport manufacturing businesses (classified directory, index of exhibitors) in Austria, Germany, Italy and Switzerland. This cross-border region represents an important area for the sport manufacturing industry (B2B). The questionnaire was predominantly answered by top-ranking managers in the respective organisations. The rate of return totalled 119 questionnaires $(n=119$; average age $=46.7$ ), with 69 coming from Tyrol and 50 from the other specified markets. Sociodemographic and related data including information about industry sector, function in the company, nationality and gender, as well as specific information about the sport manufacturing businesses were collected (Table 1).

The first research question explored the main factors determining the attractiveness of a location for sport manufacturing businesses. To arrive at an answer, the interviewees were asked to respond to 57 statements, which described variables influencing a destination's attractiveness as a possible location for sport manufacturing businesses. The abovementioned variables (1-7) were measured with a 5-point Likert scale, ranging from "very important" to "not important". Due to the large number of variables included in the survey, it was decided to conduct a factor analysis in accordance with Homburg \& Giering (1996) to see which variables load on certain factors (Table 2). Poor factor loadings (loadings $<0.600$ ) were excluded.

To account for the variance caused by variables not directly linked to our hypotheses, we performed controls for a number of firm-specific factors. Specifically, the study controlled for Age, Gender, Education and Nationality. A series of hierarchical linear regression analyses was conducted to test for $\mathrm{H} 1-\mathrm{H} 9$ (Ta- ble 4) with a view to summarising which of the proposed nine factors (extracted by the EFA) has a direct influence on the attractiveness of a location for sport manufacturing companies. The identification of the factors of attractiveness when it comes to choosing a location for a sport manufacturing business, leads us to the second research question, "What are the most important issues for sport manufacturing businesses when making location decisions?" As explained above, respondents were asked to answer 57 statements, which described variables influencing a destination's attractiveness as a possible location for a sport manufacturing business (5-point Likert scale). A descriptive analysis in the two samples, Tyrol and Others, gives an overview of the items that scored highest for the overall sample (mean value) (Table 5).

\section{Results}

Factors describing a destination's attractiveness as a potential location for sport manufacturing businesses

In order to answer the first research question, 57 attraction variables were factor analysed to determine the overall attraction dimensions. Nine factors, explaining $82.42 \%$ of the overall variance, were identified as attraction dimensions (Table 2). All items referring to a destination's attractiveness as a possible location for sport manufacturing businesses were included, whereas items not referring to attractiveness (e.g. statements such as "The hospitality of the locals is very welcoming" or "The destination offers good international shopping opportunities") were excluded. Besides the high value of the Kaiser-MeyerOlkin Measure $(\mathrm{KMO}=0.896)$, the inverse correlation matrix did not show any difficulties regarding the factor analysis. Moreover, Cronbach's a was used for all factors to examine reliability; nine factors could be extracted by using 36 items.

Table 1. Sociodemographic profile of the respondents

\begin{tabular}{lrll}
\hline Industry sector (\%) & & Function in the Company (\%) & \\
Sports Manufacturing & 53.8 & General Manager & 65.5 \\
Industry & & Other Position & 34.5 \\
Event Agency* & 23.5 & & \\
Ropeway Industry & 15.1 & & \\
Sales Agent * & 5.9 & Gender (\%) & \\
& & Male & 19.8 \\
\hline Nationality (\%) & 59.8 & Female & \\
Austria & 25.0 & & \\
Germany & 7.1 & & \\
Switzerland & 6.3 & & \\
Italy & 1.8 & & \\
Other & & & \\
\hline
\end{tabular}

*in the Sports Manufacturing Industry/or Ropeway Industry 
Table 2. Factors and factor loadings identified by factor analysis (EFA)

\begin{tabular}{|c|c|c|c|c|}
\hline Item Number & Statement & EFA & $\mathbf{a}$ & $\begin{array}{l}\text { Explained } \\
\text { Variance }\end{array}$ \\
\hline & Sport Events & & .963 & 42.860 \\
\hline 1 & ... the destination offers outdoor events, which are a possibility for business marketing communication. & 0.801 & & \\
\hline 2 & ... the destinations offers winter events, which are a possibility for bu siness marketing communication. & 0.718 & & \\
\hline 3 & ... the destination stands for outstanding sport and recreactional events. & 0.792 & & \\
\hline 4 & ... the destination is well-known for its professional organisation of sport events. & 0.794 & & \\
\hline 5 & ... the destination is receptive to new and special events, which can be utilised firm-specificly. & 0.685 & & \\
\hline 6 & ... events have a high number of participants. & 0.827 & & \\
\hline 7 & ... participants are satisfied with the event. & 0.885 & & \\
\hline 8 & ... events have a high number of spectators. & 0.849 & & \\
\hline 9 & ... spectators are satisfied with the event. & 0.89 & & \\
\hline 10 & ... events communicate a company's profile and brand. & 0.781 & & \\
\hline \multirow[t]{2}{*}{15} & ... the destination is well-known for its good image related to sport. & 0.645 & & \\
\hline & Sport \& Infrastructure & & .963 & 55.110 \\
\hline 19 & ... snow is a garuntee in winter at the destination. & 0.708 & & \\
\hline 48 & ... the destination offers skiing areas and other winter sports facilities. & 0.843 & & \\
\hline 49 & ... the destination offers alpine terrain and outdoor parks. & 0.722 & & \\
\hline \multirow[t]{2}{*}{51} & $\ldots$ the infrastructure within the destination is diverse and on a high quality in winter. & 0.794 & & \\
\hline & Tourism \& Marketing & & .927 & 62.310 \\
\hline 11 & ... the destination and its policy represent a sustainable tourism encouragement. & 0.71 & & \\
\hline 13 & ... goverment priorizatin of tourism. & 0.752 & & \\
\hline 14 & ... the destination's marketing presence is professional. & 0.813 & & \\
\hline \multirow[t]{2}{*}{17} & ... the destination's tourism represents high quality in times of international meetings. & 0.732 & & \\
\hline & Burden \& Bureaucracy & & .835 & 66.569 \\
\hline 35 & ... time required to start a new business or relocate an existing one is low. & 0.808 & & \\
\hline 36 & ... location costs to start a new business are low. & 0.881 & & \\
\hline \multirow[t]{2}{*}{37} & ... extent of taxation and administration costs are low. & 0.807 & & \\
\hline & Transportation Connection & & .865 & 70.195 \\
\hline 44 & ... accessability by plane to the destination is easily obtainable. & 0.847 & & \\
\hline 45 & ... accessability by train to the destination is easily obtainable. & 0.893 & & \\
\hline \multirow[t]{2}{*}{46} & ... accessability by car to the destination is easily obtainable. & 0.727 & & \\
\hline & Political Framework & & .886 & 73.674 \\
\hline 54 & ... government prioritzation of sports industry. & 0.646 & & \\
\hline 55 & ... the destination controls and evaluates its politics. & 0.785 & & \\
\hline \multirow[t]{2}{*}{56} & ... transparency of government policy making. & 0.803 & & \\
\hline & Quality of Life \& Medical Care & & .824 & 76.757 \\
\hline 31 & ... the availabilty of health facilities/medical care (specialised on sport) within the destination. & 0.759 & & \\
\hline 32 & ... the destination is running programmes in sports medicine research. & 0.721 & & \\
\hline \multirow[t]{2}{*}{34} & ... the destinatioin offers a high standard in general health facilities and medical care. & 0.715 & & \\
\hline & Employment \& Education & & .882 & 79.642 \\
\hline 23 & ... the availabilty of skilled labour, regarding the sports industry, within the destination. & 0,671 & & \\
\hline 25 & ... local availabiltiy of research \& training services for employees in the sports industy. & 0,685 & & \\
\hline \multirow[t]{2}{*}{26} & $\begin{array}{l}\text {... the destination offers an educational system (universities, universties of applied science, research facilities) with a } \\
\text { priority on sport. }\end{array}$ & 0,697 & & \\
\hline & Industry \& Innovation & & .726 & 82.424 \\
\hline 12 & ... government prioritzation of (heavy) industry. & 0,88 & & \\
\hline 40 & ... the destination is well known for industrial innovations. & 0,74 & & \\
\hline
\end{tabular}

$\mathrm{KMO}=0.896$, Varimax Rotation, Variance explained $82.42 \%$, Bartlett's Test of Sphericity $=.00$

The identified dimensions were labelled as follows: Factor 1, "Sport Events", bundles those items referring to events hosted by the destination such as winter and outdoor events and their athletes and visitors. Factor 2, "Sport \& Infrastructure", covers those items focusing on sport facilities, sport terrain diversity and quality. Factor 3, "Tourism \& Marketing", bundles those items addressing all marketing and tourism activities carried out by the destination. Factor 4 was labelled "Burden \& Bureaucracy" as these items address the extent to which the cost of starting up and running a business influences the choice of a specific business location. Factor 5, "Transportation Connection", deals with items concerning the role of transportation and overall accessibility of the destination. Factor 6, "Political Framework", bundles the items referring to the focal points and framework conditions of the government and its policies at the destination. Factor 7, "Quality of Life \& Medical Care", covers those items focusing on the availability and quality of medical services and infrastructure. Fac- 
tor 8, "Employment \& Education", bundles the items addressing the availability of qualified labour for the sports industry and opportunities for education and further training at the destination. Factor 9, "Industry \& Innovation", includes the items referring to the destination's innovation potential and its image in terms of innovation and industry. In summary, all items and constructs used in the model showed very good reliability and validity and were thus acceptable for further analysis.

A series of hierarchical regression analyses was conducted to test for H1-H9 (Figure 1). The controls (i.e., Age, Gender, Educa- tion and Nationality) were entered into the first block (Model 1) and the predictors were entered into the second block (Model 2). The findings of the regression analyses are reported in Table 4. Sport Events positively affected the Attractiveness of Location ( $\beta=.369, \mathrm{p}<.01, \mathrm{H} 1$ supported). Attractiveness did not affect Sport \& Infrastructure, Tourism \& Marketing, Burden \& Bureaucracy, Transport Links, Political Framework, Quality of Life \& Medical Care, Employment \& Education and Industry \& Innovation (see Table 4, H2-H9 not supported). The control variables did not significantly affect the dependent variables (overall construct, $M=4.059, S D=.959$ )

Table 3. Means, standard deviations and correlations for measures

\begin{tabular}{|c|c|c|c|c|c|c|c|c|c|c|c|}
\hline Variables & M & SD & 1. & 2. & 3. & 4. & 5. & 6. & 7. & 8. & 9. \\
\hline 1. Sport Events & 3.59 & 1.12 & 1.00 & & & & & & & & \\
\hline 2. Sport \& Infrastructure & 3.78 & 1.17 & $.60^{* *}$ & 1.00 & & & & & & & \\
\hline 3. Tourism \& Marketing & 3.85 & 1.12 & $.67^{* *}$ & $.68^{* *}$ & 1.00 & & & & & & \\
\hline 4. Burden \& Bureaucracy & 4.17 & .83 & $.21^{*}$ & .11 & .13 & 1.00 & & & & & \\
\hline 5. Transportation Connection & 4.17 & .84 & $.24^{* *}$ & $.29^{* *}$ & .18 & $.41^{* *}$ & 1.00 & & & & \\
\hline 6. Political Framework & 3.99 & 1.04 & $.50^{* * *}$ & $.56^{* *}$ & $.55^{* *}$ & $.35^{* *}$ & $.45^{* *}$ & 1.00 & & & \\
\hline 7. Quality of Life \& Medical Care & 3.29 & .09 & $.47^{* * *}$ & $.50^{* *}$ & $.47^{* *}$ & $.29 * *$ & $.45^{* *}$ & $.53^{* *}$ & 1.00 & & \\
\hline 8. Employment \& Education & 3.85 & 1.07 & $.59^{* *}$ & $.63^{* *}$ & $.56^{* *}$ & $.34^{* *}$ & $.37^{* *}$ & $.55^{* *}$ & $.55^{* *}$ & 1.00 & \\
\hline 9. Industry \& Innovation & 3.47 & .98 & .09 & .16 & .16 & $.41^{* *}$ & $.42^{* *}$ & $.33^{* *}$ & $.27^{* *}$ & $.27^{* *}$ & 1.00 \\
\hline
\end{tabular}

$\underline{\text { Notes }}$

$\mathrm{M}=$ mean, $\mathrm{SD}=$ standard deviation, ${ }^{*}=\mathrm{p}<.05,{ }^{* *}=\mathrm{p}<.01$.

Table 4. Results of the regression analysis

\begin{tabular}{|c|c|c|}
\hline DV: Location Attractiveness & Model 1 & Model 2 \\
\hline Controls & Beta & \\
\hline $\begin{array}{l}\text { Independent Variables } \\
\text { Sport Events } \\
\text { Sport \& Infrastructure } \\
\text { Tourism \& Marketing } \\
\text { Burden \& Bureaucracy } \\
\text { Transportation Connection } \\
\text { Political Framework } \\
\text { Quality of Life \& Medical Care } \\
\text { Employment \& Education } \\
\text { Industry \& Innovation }\end{array}$ & & $\begin{array}{c}0.369 * * \\
0.006 \\
0.180 \\
0.088 \\
0.090 \\
-0.135 \\
0.067 \\
-0.013 \\
0.006\end{array}$ \\
\hline
\end{tabular}

${ }^{*}=p<.05 ;{ }^{* *} p<.01$. Dependent variable: location attractiveness. 
Important issues concerning location decisions by sport manufacturing businesses

In order to answer the second research question, the importance of statements was analysed. The following items either scored highest or were most important for the overall sample (Table 5): "accessibility by car to the destination is easily obtainable" (4.402); "the destination's political and legal security is given" (4.390); "location costs to start up a business are low" (4.222). The lowest scores appeared for "the destination is running programmes in sports medicine research" (2.899) and "the destination offers good international shopping opportunities" (3.093). Furthermore, in the Tyrolean dataset, items like "destination is well-known for its good image related to sport" (4.44) scored very high compared to the Others dataset, where the item "extent of taxation and administration costs are low" (4.239) scored very high. When looking at the combined positive scores, indications are that Burdon \& Bureaucracy (Factor 4) and Transport Connections (Factor 5) are very important for all stakeholders. Compared to the overall results, the Tyrolean sport manufacturing businesses set a high value on a destination's good sport-related image. By contrast, the other markets gave sport and image relatively low scores (3.986) compared to the extent of taxation and administration costs, as those items constituting Factor 4 (Burden \& Bureaucracy) are considered very important.

\section{Discussion}

Summary

The purpose of the study was to provide deeper insights into the factors of attractiveness influencing the business location choices of sport manufacturing organisations. Nine factors considered pertinent for alpine tourism destinations were extracted by the EFA. Furthermore, hierarchical regression analyses were used to explore factors influencing the attractiveness of a location for sport manufacturing companies, whilst the importance of different statements was researched. Results show that 1) the sport-specific factor "Sport Events" influences the attractiveness of a sport manufacturing business location, 2) differences between Tyrol and other regions were identified relating to the importance of specific factors.

\section{Research Contribution}

A destination's attractiveness as a possible business location for sport manufacturing businesses can best be explained by the factors "Sport Events", "Sport \& Infrastructure", "Tourism \& Marketing", "Burden \& Bureaucracy", "Transport Links", "Political Framework", "Quality of Life \& Medical Care”, "Employment \& Education", and "Industry \& Innovation". First, these features are often discussed in the literature (Crouch, 2011; Zehrer et al., 2016; etc.), that is, with the exception of the sport-specific factor (such as "Sport Events") which is not a key factor in tourism literature. Its inclusion in this study, therefore, makes a valid contribution to the existing tourism and management literature. Furthermore, the factor "Sport Events" influences the attractiveness of a location for sport manufacturing businesses in the Alps. In accordance with Dixit et al. (2019) who asserted that economic and non-economic factors influence the attractiveness of a destination and that these non-economic factors are specific to the destination, it is clear that a sport event (economic factor) and the appeal generated by the event (noneconomic factor) influence the attractiveness of the Alps as a location for sport manufacturing businesses.

Second, differences between Tyrol and other regions were identified in terms of the importance of specific factors, e.g. "destination is well-known for its good image related to sport" (4.44 - overall sample scored 3.986) was very important for sport manufacturing businesses located in Tyrol. Furthermore, Tyrol scored highest for hosting many different sport events (past, present and future) and, compared to the other markets, the concentration of sport events and sport terrains is extraordinary, and therefore plays an important role (Schnitzer, Kössler, Schlemmer, \& Peters, 2020). By contrast, the "extent of taxation and administration costs are low" was an important factor for

Table 5. Listing of the most important issues concerning location decisions in sport manufacturing businesses

\begin{tabular}{|c|l|c|c|c|}
\hline $\begin{array}{c}\text { Item } \\
\text { Number }\end{array}$ & \multicolumn{1}{|c|}{ Statement } & Tyrol & Others & Total (Mean value) \\
\hline $\mathbf{4 6}$ & $\ldots$ accessibility by car to the destination is easily obtainable. & 4.34 & 4.448 & 4.402 \\
\hline $\mathbf{5 7}$ & ... the destination's political and legal security is given. & 4.44 & 4.353 & 4.39 \\
\hline $\mathbf{3 6}$ & ... location costs to start up a new business are low. & 4.2 & 4.239 & 4.222 \\
\hline & & & 4.184 & 4.239 \\
\hline $\mathbf{3 7}$ & ... extent of taxation and administration costs are low. & & 4.216 \\
\hline & & 4.44 & 3.986 & \\
\hline $\mathbf{1 5}$ & ... the destination is well-known for its good image related to sport. & & 4.176 \\
\hline
\end{tabular}

Note: 5 -point likert scale was used from: $1=$ not important to $5=$ very important 
sport manufacturing businesses outside Tyrol. The finding of differences within the Alps in terms of the importance of factors makes a firm contribution to the literature.

Third, the descriptive analysis showed that the items bundled in Factors 4, 5 and 6 are very important when making location decisions. That is in accordance with Knezevic Cvelbar, Dwyer, Koman, and Mihalic (2016) who stated that an important driver of destination competitiveness is the quality of the general infrastructure (Knezevic Cvelbar, Dwyer, Koman, \& Mihalic, 2016). In our study, the statement "...good accessibility by car; the destination is easily obtainable" (4.402) fosters that theory (bundled in Factor 5). According to the findings of Ketokivi, Turkulainen, Seppälä, Rouvinen, and Ali-Yrkkö, (2017) the cost of starting up a business, the extent of taxation and administration costs plus legal certainty at the destination are important for location choices, influencing the decisions made by sport industry managers (bundled in Factors 4 and 6). In terms of the quality of general infrastructure, costs, and burden \& bureaucracy, sport manufacturing businesses do not differ from other businesses in their choice of location.

Fourth, the present contribution is based on a specific sector (sport manufacturing companies) and is focused on sport-specific critical factors, while Sieber (2008) has called for an evaluation of location decision factors for other lines of business, too. We have contributed to sport management literature by identifying specific aspects that come into play when sport manufacturing companies choose a business location.

\section{Managerial Implications}

The sport-specific factor Sport Events is not, however, a key factor in tourism and management literature, but should certainly be on the radar of destination managers and governments seeking to attract sport manufacturing businesses. By supporting and reinforcing sport events, destinations can set themselves apart from other destinations. Furthermore, managers of sport manufacturing businesses should take the factor "Sport Event" into consideration when making location decisions.

The descriptive analysis showed that the items bundled in factors like transport links, the cost of starting up a business, the extent of taxation and administration costs plus legal certainty at the destination are very important for sport industry managers and influence their decisions. The Alps have high costs compared to other industrial regions in terms of e.g. land; nevertheless, governments and regions have to ensure that they create a attractive region without relying only on the beauty and appeal of the landscape (Ketokivi et al., 2017)

Tyrol scored highest for "... the destination is well-known for its good image related to sport" (4.44 - overall sample scored 3.986). Tyrol is driven by tourism, hosts many different sport events (past, present and future) and, compared to the other markets, the concentration of sport events and sport terrains is extraordinary, and therefore plays an important role. The other regions did not score that high for sport-related image, albeit totalling 3.986 - it may be concluded that sport events and sport-related image are important for all regions and influences the attractiveness of sport businesses, with slightly regional differences. This is precisely what destinations and locations can use as a great indicator when positioning themselves as a benchmark and as an attractive location for sport manufacturing businesses.

\section{Limitations and future research}

This study includes certain limitations. First, data were generated from a single respondent from each company; seeking the opinions of more organisational stakeholders such as employees would have lent greater validity to the reported findings. Second, the study focuses only on the German-speaking Alps; we did not include the whole area of the Alps or other regions in our study which would allow possible geographic particularities to be identified such that generalisability and external validity may be affected by that limitation. Third, the purpose of this study was to examine what factors affect location decisions in the sport manufacturing industry; hence, we did not seek to assess the detailed weighting of the particular factors. Fourth, only one of the proposed independent variables (Sport Events) can be significantly associated with attractiveness of location (dependent variable).

Further research should consider the development of a weighting system according to the different impacts of the dimensions on overall attractiveness, which would be an important step to improving the analytical outcome of such studies, furthermore the identification of variables associated with attractiveness of location would be very interesting.

\section{Funding}

The author has no funding or support to report.

\section{Competing Interests}

The author has declared that no competing interests exist.

\section{Data Availability Statement}

All relevant data are within the paper.

\section{References}

Ahsan, M. \& Musteen, M. (2011). Multinational enterprises' entry mode strategies and uncertainty: a review and extension. International Journal of Management Reviews, (13), 376-392.

Alcacer, J., Dezsö, C.L., \& Zhao, M. (2013). Firm rivalry, knowledge accumulation, and MNE location choices. Journal of International Business Studies, 44, 504-520. 
Andrades, L., Sanchez, M., \& Pulido, J. (2012). Differentiating Competitiveness through Tourism Image Assessment: An Application to Andalusia. Journal of Travel Research, 52(1), 68-81.

Assaf, A.G. \& Dwyer, L. (2013). Benchmarking International Tourism Destinations. Tourism Economics, 19(6), 1233-1247.

Balbontin, C., \& Hensher, D. A. (2019). Firm-specific and location-specific drivers of business location and relocation decisions. Transport Reviews, 39(5), 569-588.

Barros, C. P., Botti, L., Peypoch, N., Robinot, E., Solonandrasana, B., \& Assaf, A. G. (2011). Performance of French Destinations: Tourism Attraction Perspectives. Tourism Management, 32(1), 141-146.

Bhawsar, P. \& Chattopadhyay, U. (2015). Competitiveness: review, reflections and directions. Global Business Review, 16(4), 665-679.

Buhalis, D. (2000). Marketing the Competitive Destination of the Future. Tourism Management, 21(1), 97-116.

Cracolici, M. F. \& Nijkamp, P. (2008). The attractiveness and competitiveness of tourist destinations: A study of Southern Italian regions. Tourism Management, 30(7), 336-344.

Crouch, G. I. \& Ritchie, J. B. (1995). Destination competitiveness and the role of the tourism enterprise. Proceedings of the Fourth Annual World Business Congress, July 13-16, Istanbul, Turkey; 43-48.

Crouch, G. I. \& Ritchie, J. B. (1999). Tourism, competitiveness, and societal prosperity. Journal of Business Research, 44(3), 137-152.

Crouch, G. (2011). Destination Competitiveness: An Analysis of Determinant Attributes. Journal of Travel Research, 50(1), 27-45.

D'Cruz, J. R. \& Rugman, A. M. (1993). Developing international competitiveness: The five partners model. Business Quarterly, 58(2), 60-72.

Deng, P. (2012). The internationalization of Chinese firms: a critical review and future research. International Journal of Management Reviews, (14), 408-427.

d'Hauteserre, A. M. (2000). Lessons in Managed Destination Competitiveness: The Case of Foxwoods Casino Resort. Tourism Management, 21(1), 23-32.

Dixit, A., Clouse, C., \& Turken, N. (2019). Strategic Business Location Decisions: Importance of Economic Factors and Place Image. Rutgers Business Review, 4(1), 73-91.

Dunning, J. H. (1993). Internationalizing Porter's diamond. Management International Review, 7-15.

Dunning, J.H. (2007). A new Zeitgeist for international business activity and scholarship. European Journal of International Management, 1, 278-301.

Dwyer, L., Forsyth, P., \& Rao, P. (2000). The Price Competitiveness of Travel and Tourism: A Comparison of 19 Destinations. Tourism Management, 21(1), 9-22.

Dwyer, L. \& Kim, C. (2003). Destination Competitiveness: Determinants and Indicators. Current Issues in Tourism, 6(5), 369-414.
Dwyer, L. (2010). Destination Competitiveness: An Overview of Some Issues. Retrieved from https://issuu.com/assis.coeIho/docs/competitiv2010-dwyer

Dwyer, L., Knežević Cvelbar, L., Edwards, D., \& Mihalič, T. (2013). Tourism Firms' Strategic Flexibility: The Case of Slovenia. International Journal of Tourism Research, 16(4), 377-387.

Dwyer, L., Knežević Cvelbar, L., Mihalič, T., \& Koman, M. (2014). Integrated Destination Competitiveness Model: Testing Its Validity and Data Accessibility. Tourism Analysis, 19(1), 1-17.

Dwyer, L., Armenski, T., Knežević Cvelbar, L., Dragićević, V., \&Mihalič, T. (2014). Achieving Destination Competitiveness: An Importance-Performance Analysis of Serbia. Current Issues in Tourism. doi:10.1080/1 3683500.2014.944487

Dwyer, L., Dragićević, V., Armenski, T., Mihalič, T., \& Knežević Cvelbar, L. (2016). Achieving destination competitiveness: an importance-performance analysis of Serbia. Current Issues in Tourism, 19(13), 1309-1336.

Dziemianowicz, W., Łukomska, J., \& Ambroziak, A. A. (2019). Location factors in foreign direct investment at the local level: the case of Poland. Regional Studies, 53(8), 1183-1192.

Enright, M. J. \& Newton, J. (2004). Tourism Destination Competitiveness: A Quantitative Approach. Tourism Management, 25(6), 777-788.

Enright, M. J. \& Newton, J. (2005). Determinants of Tourism Destination Competitiveness in Asia Pacific: Comprehensiveness and Universality. Journal of Travel Research, 43(4), 339-350.

Formica, S. \& Uysal, M. (2006). Destination Attractiveness Based on Supply and Demand Evaluations: An Analytical Framework. Journal of Travel Research, 44(5), 418-430.

Funk, D. (2017). Introducing a Sport Experience Design (SX) framework for sport consumer behaviour research. Sport Management Review, 20(20), 145-158.

Gammelsæter, H. (2020). Sport is not industry: bringing sport back to sport management. European Sport Management Quarterly, DOI: 10.1080/16184742.2020.1741013.

Goerzen, A., Asmussen, C.G., \& Nielsen, B.B. (2013). Global cities and multinational enterprise location strategy. Journal of International Business Studies, (44), 427-450.

Grant, R. M. (2005). Contemporary strategy analysis. Malden, MA: Blackwell Publishing.

Hess, R., Nicholson, M., Stewart, B., \& De Moore, G. (2008). A national game: A history of Australian Rules Football. Camberwell: Viking Penguin.

Homburg, Ch. \& Giering, A. (1996). Konzeptualisierung und Operationalisierung komplexer Konstrukte: Ein Leitfaden für die Marketingforschung. Marketing: Zeitschrift für Forschung und Praxis, 18(1), 5-24.

Hu, Y. \& Ritchie, J. B. (1993). Measuring destination attractiveness: A contextual approach. Journal of Travel Research, 32(2), 25-34.

Hudson, S., Ritchie, B., \& Timur, S. (2004). Measuring Destination Competitiveness: An Empirical Study of Canadian Ski Resorts. Tourism and Hospitality Planning \& Development, 1(1), 79-94. 
Huybers, T. \& Bennett, J. (2003). Inter-firm cooperation at nature-based tourism destinations. Journal of Socio-Economics, 33(5), 571-587.

Ketokivi, M., Turkulainen, V., Seppälä, T., Rouvinen, P., \& AliYrkkö, J. (2017). Why locate manufacturing in a high-cost country? A case study of 35 production location decisions. Journal of Operations Management, 49, 20-30.

Kim, J.U. \& Aguilera, R.V. (2016). Foreign Location Choice: Review and Extensions. International Journal of Management Reviews, (18), 133-159.

Kim, N. \& Wicks, B. E. (2010). Rethinking Tourism Cluster Development Models for Global Competitiveness. International CHRIE Conference-Refereed Track, Event (28).

Knežević Cvelbar, L., Dwyer, L., Koman, M., \& Mihalič, T. (2016). Drivers of Destination Competitiveness in Tourism. A Global Investigation. Journal of Travel Research, 55(8), 1041-1050.

Knoll, N. (2004). International orientierte Unternehmen in Österreich. Rahmenbedingungen für Steuerungsfunktionen und Forschungskompetenz. Retrieved from http://www. wifo.ac.at/jart/prj3/wifo/resources/person_dokument/ person_dokument.jart?publikationsid=25272\&mime_ type=application/pdf

Kozak, M. (2003). Measuring Competitive Destination Performance: A Study of Spain and Turkey. Journal of Travel and Tourism Marketing, 13(3), 83-110.

Kuščer, K. \& Mihalič, T. (2014). Determining important environment for mountain destination development. Acta Turistica, 26(2), 103-129.

Lee, C.F., Huang, H.I., \& Huery-Ren, Y. (2010). Developing an evaluation model for destination attractiveness: Sustainable forest recreation tourism in Taiwan. Journal of Sustainable Tourism, 18(6), 811-828.

Liu, D. (2016). Social impact of major sports events perceived by host communities. International Journal of Sports Marketing and Sponsorship, 17(1), 78-91.

Lohman, C., Fortuin, L., \& Wouters, M. (2004). Designing a performance measurement system: A case study. European Journal of Operational Research, 156, 267-286.

Mangan, J.A. \& Nauright, J. (2000). Sport in Australasian society: Past and present. London: $\mathrm{F}$ Cass.

Marks-Bielska, R. \& Serocka, I. (2018). The Impact of Warmia and Masuria Local Authorities on Entrepreneurship Development in the Business Location Factors Context. Folia Oeconomica Stetinensia, 18(1), 67-81.

Mihalič, T. (2000). Environmental Management of a Tourist Destination: A Factor of Tourism Competitiveness. Tourism Management, 21(1), 65-78.

Omerzel Gomezelj, D. \& Mihalič, T. (2008). Destination Competitiveness-Applying Different Models, the Case of Slovenia. Tourism Management, 29(2), 294-307.

Onstein, A. T., Tavasszy, L. A., \& van Damme, D. A. (2019). Factors determining distribution structure decisions in logistics: a literature review and research agenda. Transport Reviews, 39(2), 243-260.
Pan, S. \& Ryan, C. (2007). Mountain areas and visitor usage motivations and determinants of satisfaction: The case of Pirongia Forest Park, New Zealand. Journal for Sustainable Tourism, 15(3), 288-308.

Pechlaner, H., Pichler, S., \& Herntrei, M. (2012). From Mobility Space towards Experience Space: Implications for the Competitiveness of Destinations. Tourism Review, 67(2), 34-44.

Porter, M. E. (1990). The Competitive Advantage of Nations. New York: The Free Press.

Reichheld, F. F. (2003). The one number you need to grow. Harvard Business Review, 81(12), 46-55.

Reitsamer, B. F., Brunner-Sperdin, A., \& Stokburger-Sauer, N. E. (2016). Destination attractiveness and destination attachment: The mediating role of tourists' attitude. Tourism Management Perspectives, 19, 93-101.

Ritchie, J. R. B. \& G. I. Crouch. (2003). The Competitive Destination: A Sustainable Tourism Perspective. Wallingford: Cabi Publishing.

Schirpke, U., Meisch, C., Marsoner, T., \& Tappeiner, U. (2018). Revealing spatial and temporal patterns of outdoor recreation in the European Alps and their surroundings. Ecosystem Services, 31, 336-350.

Schnitzer, M., Kössler, C., Schlemmer, P., \& Peters, M. (2020). Influence of Event and Place Image on Residents' Attitudes Toward and Support for Events. Journal of Hospitality \& Tourism Research, 1096348020919502.

Sieber, S. (2008). Österreichische Attraktivität für ausländische Direktinvestitionen sowie als Standort für Headquarters-Funktionen. Retrieved from http://www.wifo.ac.at/ publikationen?detail-view=yes\&publikation_id=60075

Slack, T. (2003). Sport in the global society: Shaping the domain of sport studies. International Journal of the History of Sport, 20(4), 118-129.

Sportmarken und Sportfirmen Webkatalog: Übersicht (Sport brands \& sport companies web catalogue: overview). [online] http://www.spoteo.de/sport-firmen (Accessed 24 January 2019).

Szymanski, S. (2009) Playbooks and checkbooks: An introduction to the economics of modern sports, Princeton University Press, Princeton.

Tsai, H., Song, H., \& Wong, K. K. F. (2009). Tourism and Hotel Competitive Research. Journal of Travel \& Tourism Marketing, 26(5/6), 522-546.

Uysal, M. \& Formica, S. (2006). Destination Attractiveness Based on Supply and Demand Evaluations: An Analytical Framework. Journal of Travel Research, 44(4), 418-430.

Wang, W. C., Lin, C. H., Lu, W. B., \& Lee, S. H. (2019). When destination attractiveness shifts in response to climate change: tourists' adaptation intention in Taiwan's Kenting National Park. Current Issues in Tourism, 22(5), 522543.

WEF (World Economic Forum). (2015). The Travel \& Tourism Competitiveness Report. Growth through Shocks. Geneva: World Economic Forum. 
Yacob, S., Johannes, J., \& Qomariyah, N. (2019). Visiting Intention: A Perspective of Destination Attractiveness and Image in Indonesia Rural Tourism. Sriwijaya international journal of dynamic economic and business, 3(2), 122-133.

Zehrer, A., Smeral, E., \& Hallmann, K. (2016). Destination Competitiveness - A Comparison of Subjective and Objective Indicators for Winter Sports Areas. Journal of Travel Research, 56(1), 55-66. 


\section{Appendix A}

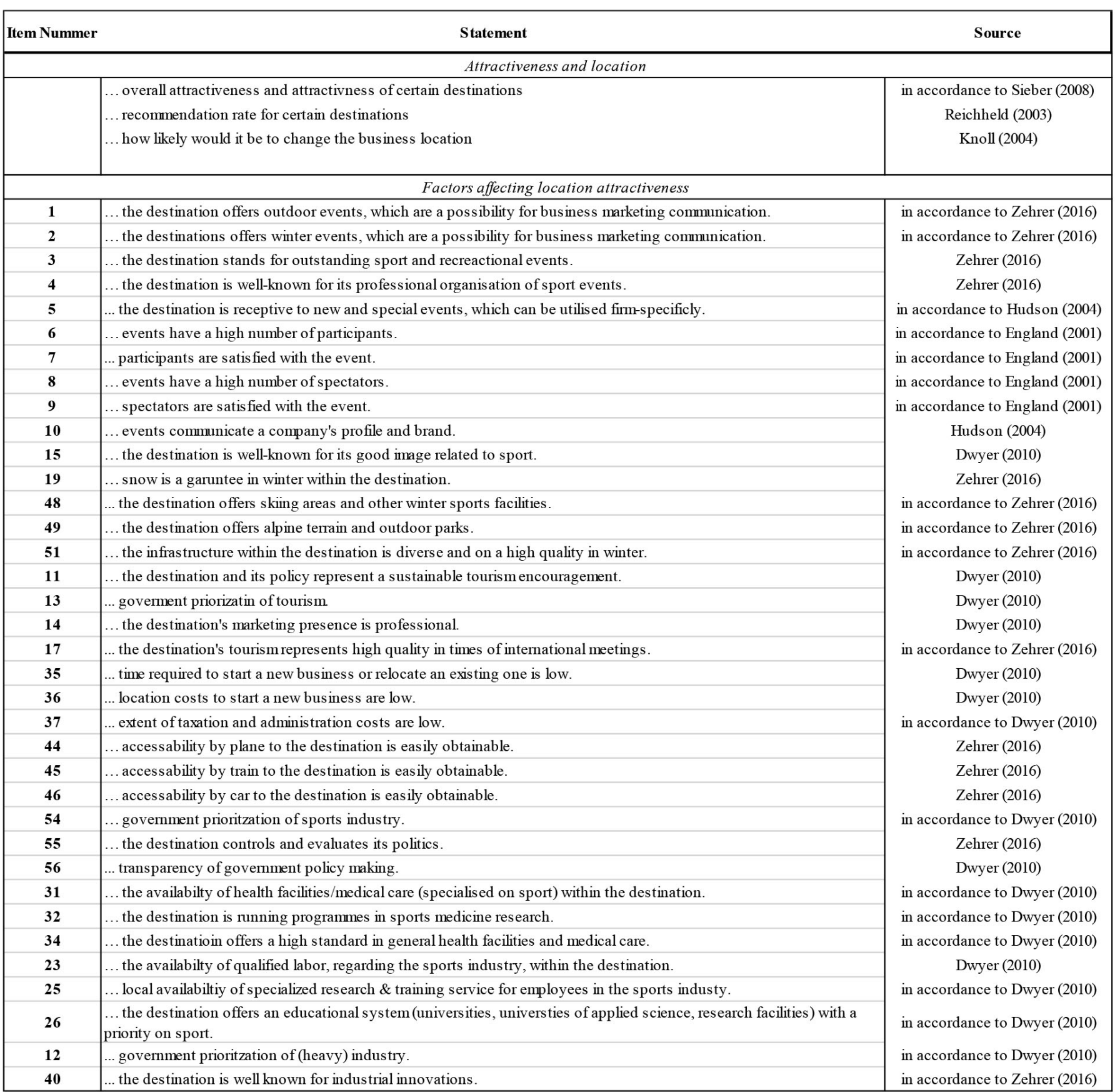

